\title{
AGE AND DEPOSTIIONAL ENVIRONMENT OF MIOCENE AND PLIOCENE ROCKS IN JACKSON HOLE (TETON COUNTY), WYOMING
}

\author{
Anthony D. Barnosky \\ Department of Geological Sciences AJ-20 \\ University of washington
}

Seattle

\section{Objectives}

Field work in 1982 completed the data collection for a 3-year project to study the Neogene geology and mammlian paleontology of Jackson Hole. The primary objectives are to more precisely determine the age of Miocene and Pliocene rocks in the area, and to clarify the depositional environment of the Miocene Colter Formation (Barnosky, 1980, 1981).

\section{Methods}

Ages of rocks were determined by biostratigraphic methods. $\mathrm{K}-\mathrm{Ar}$ age-determinations were attempted for two semples from the Colter Formation, but proved unsatisfactory for two reasons. Exotic as well as authigenic crystals of sanidine occur in the tuffs, and glass sharảs contain unbroken bubbles that apparently contain original magmatic argon (H. Krueger, Geochron Laboratories, pers. com., 1982). Anomolously ald age-determinations resulted (approximateily $30 \mathrm{my}$ on glass shards, and $217 \mathrm{my}$ on sanidine crystals).

Field observations, examination of thin-sections, and rapid-rock and X-ray fluorescence analyses were used to determine the depositional environment of the Colter Formation.

\section{Results}

Assemblages of fossil mammals show the base of the Colter Formation to be late-middle or late Arikareean in age (ca. 25-21 my old), wheras about $280 \mathrm{~m}$ above the base it is early or middle Hemingfordian (ca. 20-18 my old). The highest assemblages, locatea some $680 \mathrm{~m}$ above the base, suggest a latest Barstovian or earliest Clarendonian "age" (ca. Il my oid). Further study of genera listed in Table $I$ is underway and will allow specific identifications to increase the accuracy of the age-determinations.

Features of the Colter Formation suggest that it was deposited on and near the flanks of volcanoes, most of which were located a few $\mathrm{km}$ northwest of the Pilgrim Creek area. Figure 1 shows the landscape of Jackson Hole as it may have appeared during latest Barstovian time and summarized the evidence for the reconstruction. The block is cut approximately through the modern 


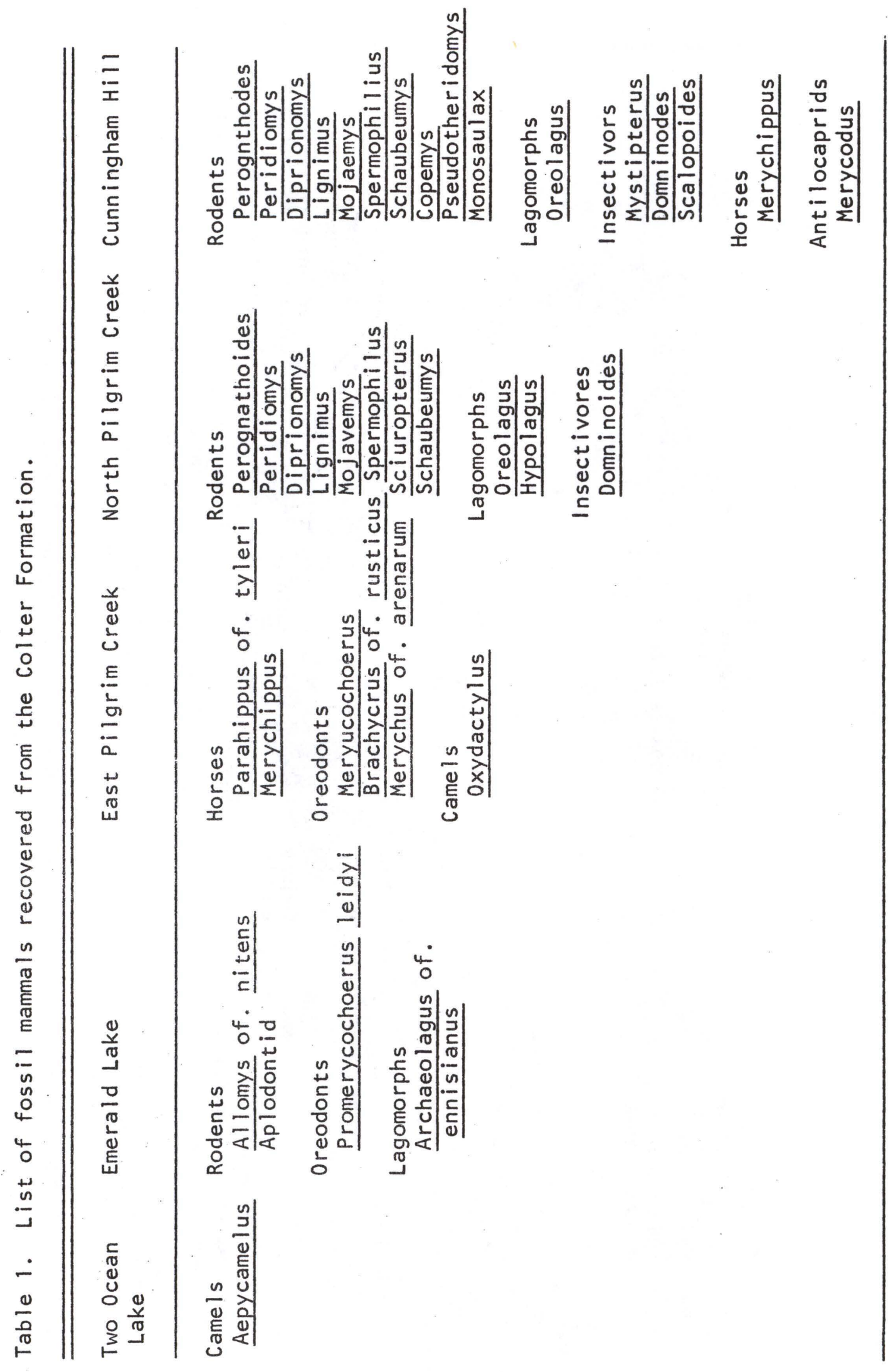




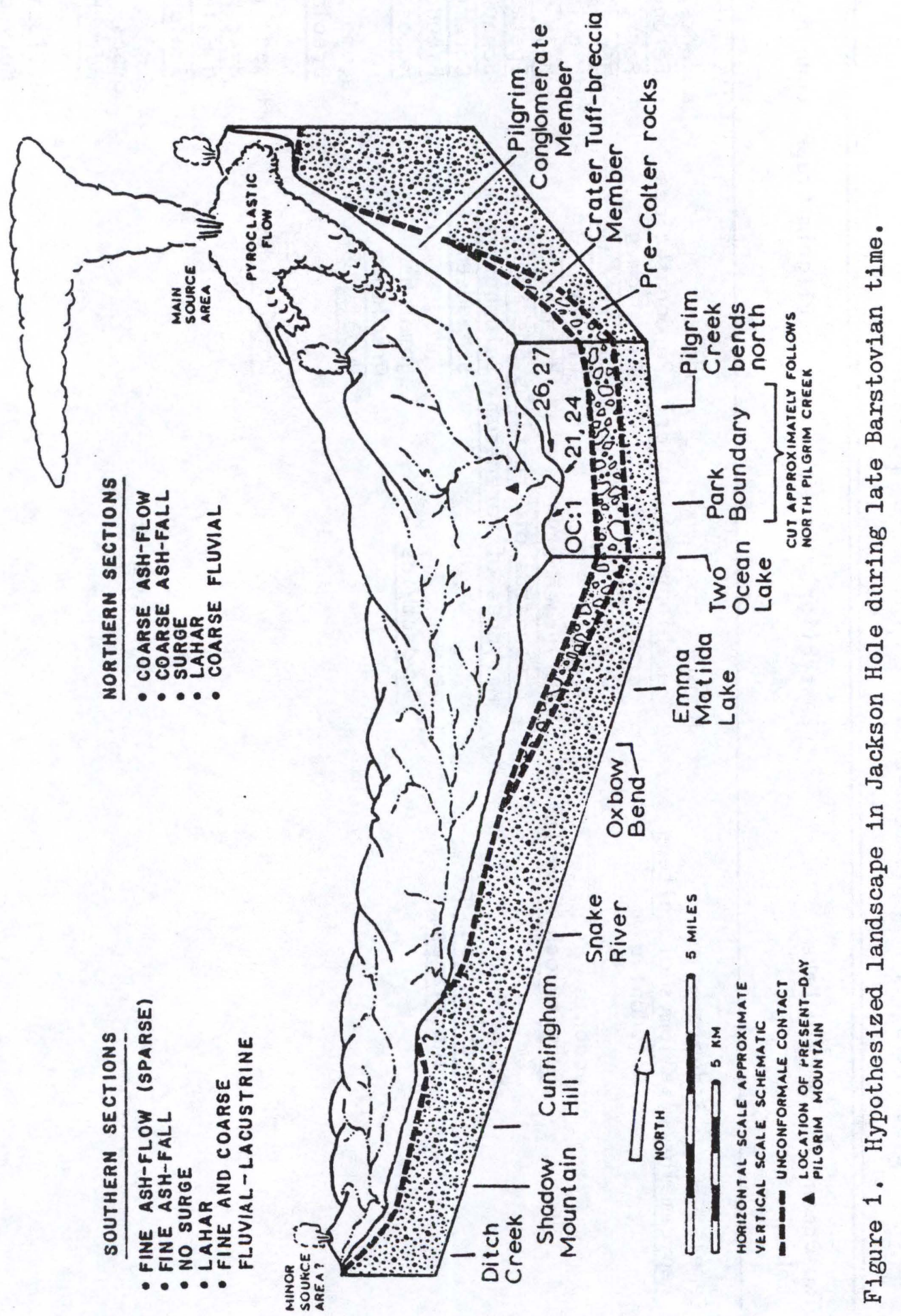


topographic features labelled along the bottom.

Lithologic aspects of the Colter Formation suggest that it should be divided into two members, with andesitic, trachytic, and latitic tuff and ignimbrite characterizing the lower one. The upper member, comprising about two-thirds of the formation, consists primarily of rhyolitic rocks. Names of members on Figure 2 have not yet been formally accepted.

Chemical and field evidence imply that the lower member accumulated in conjunction with a compressive tectonic regime, wheareas the upper member relates to extensional tectonism.

Table 2 lists species of rodents that were recovered from the Shooting Iron Formation where it outcrops along Boyle Ditch in the National Elk Refuge. The rodents show the formation to be late Blancan in age (ca. 2.6-2.0 my old). Some of the fossils are pictured in Figure 2. Most of these microtines seem more closely related to contemporaneous forms on the Great Plains rather than to those west of the rocky Mountains, which suggests a major shift in biogeographic provinces since the late Pliocene.

\section{Conclusions}

The Colter Formation ranges in age from the late Arikareean to latest Barstovian or earliest Clarendonian. It can be divided into two members, both of which accumulated within a few tens of $\mathrm{km}$ of a volcanic source area. The lower member indicates a compressive tectonic regime from late Arikareean to early or mirdle Hemingfordian time. Extensional tectonics apparently prevailed by the time the upper member was deposited during the latest Barstovian and/or earliest Clarendonian. Volcanism during the Miocene probably took place along the same planes of weakness that later developed into the ieton Fault system.

The base of the Shooting Iron Formation was deposited during late Blancan time. Evolutionary affinities of the microtine rodents suggest that since the late Blancan, the border between eastern and western biogeographic provinces shifted eastward.

\section{Iiterature Cited}

Barnosky, A. D. 1980. Biostratigraphic and biogeographic implications of Miocene mammals from Jackson Hole, Wyoming. UW-NPS Res. Cen. Fourth Ann. Rept.:24-27. 1981. Geology and Mammalian Paleontology of Neogene Strata in
Jackson Hole, Wyoming. Uwं-NPS Res. Cen. Fifth Ann. Rept:3 pp. 

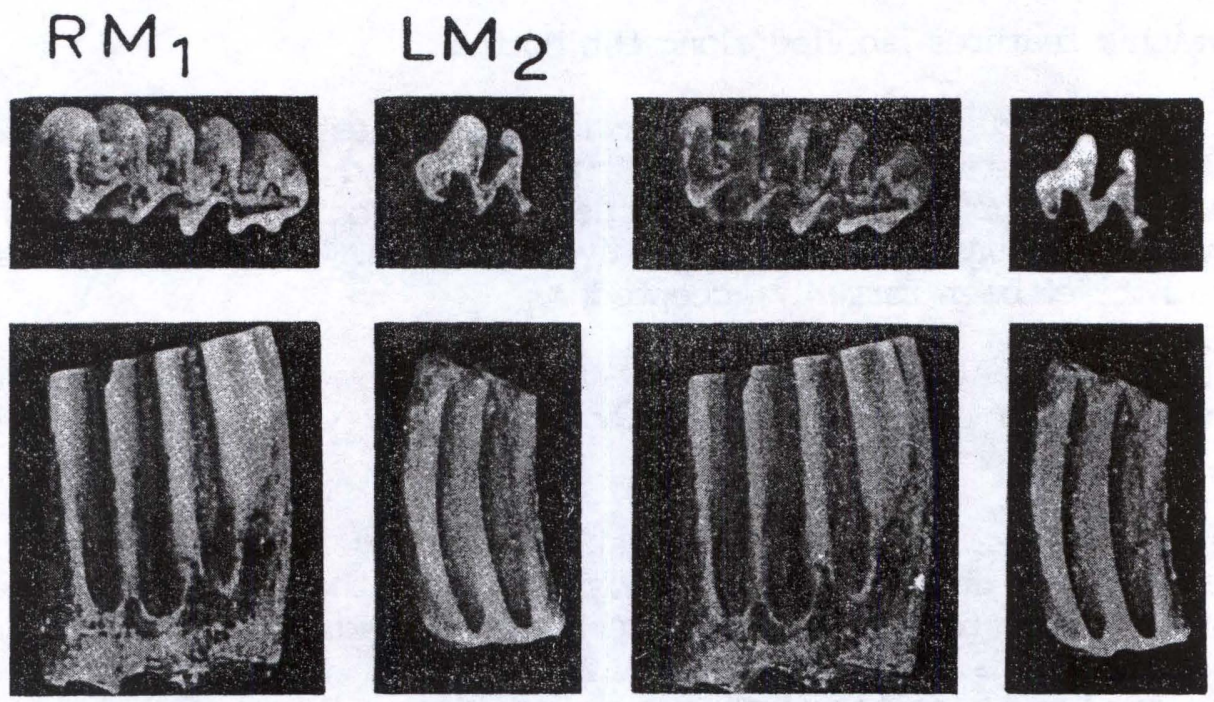

a
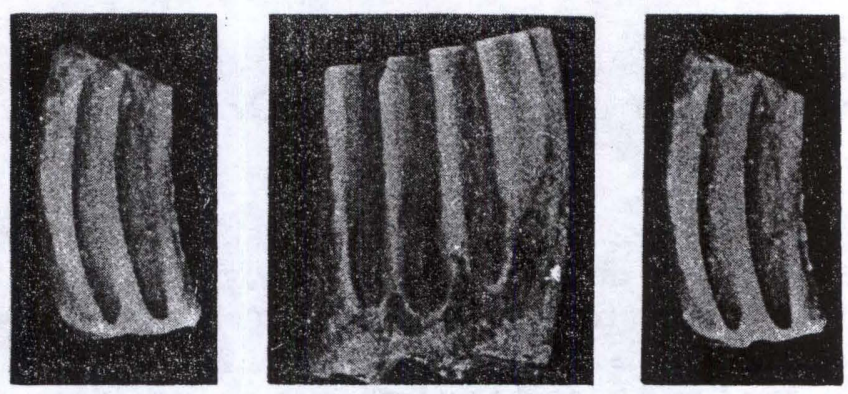

b

\section{Pliophenacomys primaevus}
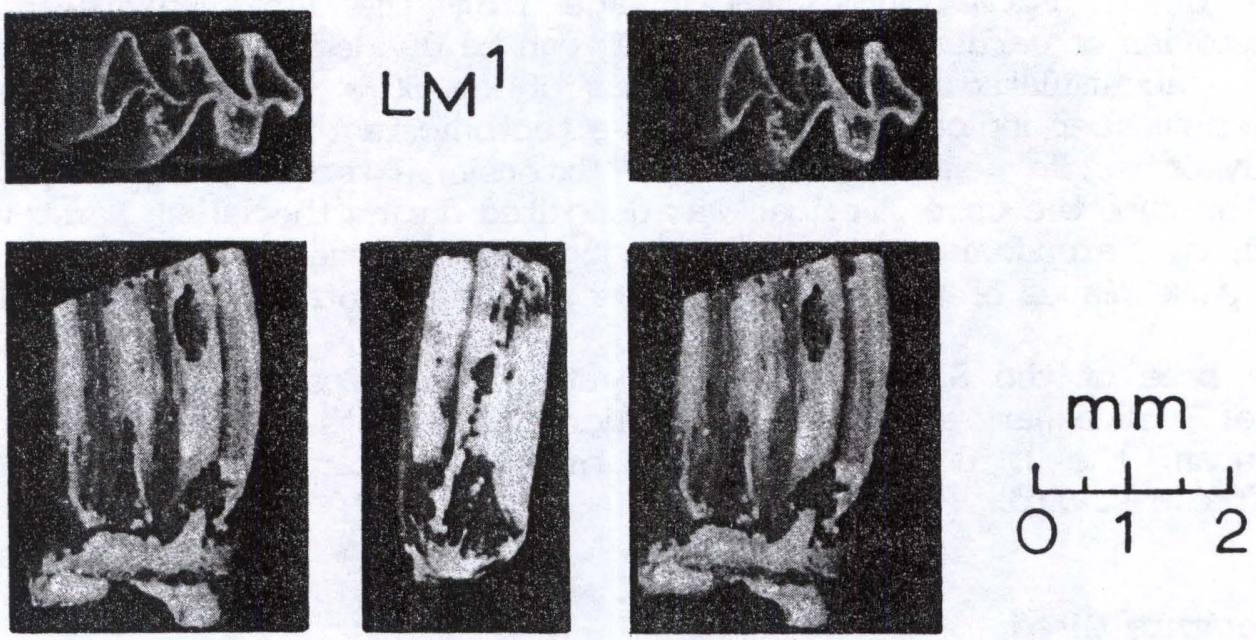

C

d

Figure 2. Fossil molars of Pliophenacomys primaevus, a microtine rodent of late Pliocene age. Fossils were collected from sediments on the National Elk Refuge. All but d are stereo pairs. 
Table 2. Microtine rodents from the Shooting Iron Formation in the National Elk Refuge.

Ondatra near idahoensis (Muskrat)

Ophiomys meadensis (Meade Snake river vole)

Plicphenacomys primaevus (Primeval voie)

Synaptomys sp. (bog lemming) 